\title{
Effect of soil extracts concentration on specific growth rate and lipid content of Chlorella vulgaris in Bolds Basal Medium.
}

\author{
M. Atta, A. Bukhari,C.L.Teo, A. Idris* \\ Department of bioprocess engineering, Faculty of chemical engineering, UTM, 81310 UTM Skudai, Johor, Malaysia \\ *Corresponding Author: ani@cheme.utm.my (Ani Idris)
}

\section{Article history :}

Received 4 March 2014

Revised 1 April 2014

Accepted 20 May 2014

Available online 1 June 2014

GRAPHICAL ABSTRACT

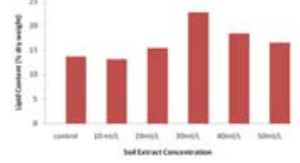

\begin{abstract}
Effective nutrient medium is the key factor that significantly influences the specific growth rate and the final concentration of microalgae. The main objective of this study was to increase the microalgal growth in mass culture system under the effect of soil extract in the modified Bolds Basal medium. Chlorella vulgaris was grown asceptically for 10 days at five different concentrations of soil extract $(10,20,30,40$, and $50 \mathrm{ml} / \mathrm{L}$ ) at $25^{\circ} \mathrm{C}$ cultivation temperature. After 10 days of cultivation, Chlorella vulgaris showed maximum cell concentration of $5 \times 10^{7} / \mathrm{ml}$ at $30 \mathrm{ml} / \mathrm{L}$ of soil extract concentration which corresponds to the maximum specific growth rate $1.56 \mu \mathrm{d}^{-1}$ with the doubling rate of $2.25 \mathrm{~d}^{-1}$ and lipid yield of $22.74 \%$ of dry weight.
\end{abstract}

Keywords: Specific growth rate, Chlorella vulgaris, Soil extract, Bolds basal medium

C) 2014 Penerbit UTM Press. All rights reserved http://dx.doi.org/10.11113/mjfas.v10n2.259

\section{INTRODUCTION}

Developments in microalgae biotechnology not only leads to the production of high lipid content and production of green energy, but also contributes to the nutraceutical, pharmaceutical, cosmetics, human and animal food industries [1]. In addition, microalgal biomass also has wide range of application in energy conversion processes such as biochemical conversion (anaerobic fermentation, aerobic digestion and photo biological hydrogen production), thermochemical conversion (gasification, direct combustion and pyrolysis) and production of biodiesel from transesterification of FAME (fatty acid methyl ester) [2]. Although microalgae biomass is widely used, its commercial scale applications are still limited because of the low yield and high cost of microalgal products [3].

Microalgae have a vast potential of doubling their biomass during exponential phase within 24 hours or very short period of (210 min). [4] Biomass growth and its chemical composition of microalgae are mainly dependent on the quality (source) and quantity intensity, percentage of carbon and nitrogen in growing media. Growth conditions such as temperature, $\mathrm{pH}$ removal and oxygen are important factors that affect biomass growth [5]. Algal cell requires inorganic nutrients that must be provided by the efficient growth medium which includes essential elements such as nitrogen, phosphorus, iron and silica. Generally growth media are inexpensive. To acquire sufficient microalgal biomass, Grobellar (2004) suggested a formula (CO0.48H1.83N0.11P0.01) which estimated minimum nutritional requirement of a microalgal cell growth. Supply of significant quantity of macronutrients such as phosphorous is compulsory to the algal cell as most of the phosphorus makes complex with metal ions, therefore, the bioavailability of phosphorous is limited to the required algal growth [6].

Cultivation of marine microalgae requires nitrate and phosphate fertilizers, and some other micronutrients for their growth media [7]. Micronutrients such as Co, Mn, Zn, and $\mathrm{Cu}$ are essential for microalgal growth as they help in many metabolic processes such as photosynthesis and energy storage [8]. Widely available Chlorella vulgaris belongs to phylum Chlorophyta is a green, single celled fresh water microalgae, rich in nutritious values. Its fast growth rate, robustness, high lipid content and readily adaptive behavior to culture conditions (autotrophic, mixotrophic, heterotrophic) is supportive to optimize biomass and lipids productivity [9].

Chlorella. vulgaris is an autotrophic as well as heterotrophic and can be easily grown on media rich in chemicals and sewage. Although soil has an oligotrophic environment it contains all the necessary elements for the optimum growth of microalgae when cultivated in an artificial medium [10]. Soil extract play a critical role in the enhancement of biomass of Chlorella vulgaris, this is due the composition of soil extract which are nitrogen, sulphur phosphorus calcium and magnesium. These elements are 
supposed to have important effects with the formation of protein and green mold on Chlorella vulgaris.Phosphorus and calcium also play a role in cell division promoting faster cell division, increase cell density, specific growth rate resulting in faster algal growth [11]. Chen et al reported the reduced accumulation of lipid content of Dunaliella tertiolecta when deprived with iron or cobalt at the $7^{\text {th }}$ day of cultivation period and no significant amount of accumulation of lipid content when cells were deprived of manganese, molybdenum or zinc. [12] In order to get improved growth of Chlorella vulgaris, selection of suitable media and its composition is an important factor.

Therefore the aim of this study was to evaluate the effect of soil extract concentration in the modified Bolds Basal media on the cell density, specific growth rate division rate and lipid content of Chlorella vulgaris. The behavior of Chlorella vulgaris towards biomass production can be investigated by cultivating it at five different concentrations of soil extract $(10,20,30,40,50 \mathrm{ml} / \mathrm{L})$.

\section{EXPERIMENTAL}

\subsection{Soil extract}

Humus rich fertile soil was purchased from the local nursery in Johor Bahru Malaysia. The soil was air dried. The air-dried, sieved soil was then mixed 1:1 with distilled water, and particles were removed by settling for $2 \mathrm{~h}$ and were centrifuged $\left(5,000 \times \mathrm{g}, 20^{\circ} \mathrm{C}, 20 \mathrm{~min}\right)$. The supernatant was filter sterilized (pore size, $0.2 \mu \mathrm{m}$ ) and then autoclaved. The soil solution was left for a few days and the supernatant was decanted off, stored in the refrigerator for later use.

\subsection{Microalgae media and cultivation}

Fresh water microalga Chlorella vulgaris was obtained from Algae Tech research institute Kuala Lumpur, Malaysia. Chlorella vulgaris was cultivated in a modified soil extract Bolds Basal medium (SEM) of composition: $\mathrm{KNO}_{3}, 1.25 ; \mathrm{KH}_{2} \mathrm{PO}_{4}, 1.25 ; \mathrm{MgSO}_{4} .7 \mathrm{H}_{2} \mathrm{O}, 1 ; \mathrm{CaCl}_{2}$, 0.0835; $\quad \mathrm{H}_{3} \mathrm{BO}_{3}, \quad 0.1142 ; \quad \mathrm{FeSO}_{4} .7 \mathrm{H}_{2} \mathrm{O}, \quad 0.0498$; $\mathrm{ZnSO}_{4} .7 \mathrm{H}_{2} \mathrm{O}, \quad 0.0882 ; \mathrm{MnCl}_{2} . \quad 4 \mathrm{H}_{2} \mathrm{O}, 0.0144 ; \mathrm{MoO}_{3}$, 0.0071; $\mathrm{CuSO}_{4} .5 \mathrm{H}_{2} \mathrm{O}, 0.0157$; $\mathrm{Co}\left(\mathrm{NO}_{3}\right) 2.6 \mathrm{H}_{2} \mathrm{O}, 0.0049$; EDTA. $2 \mathrm{Na}, 0.5 \mathrm{~g} / \mathrm{L}$ in $500 \mathrm{ml}$.

\subsection{Cultivation of Chlorella vulgaris}

Preparation of inoculum was done by transferring the cells from stock culture into $500 \mathrm{ml}$ flask containing $250 \mathrm{ml}$ culture media in an incubator, maintained under continuous white light (fluorescent lamp TL5 of intensity $2 \times 18$ W). Continuous bubbling was done by an air pump with a flow rate of $150 \mathrm{ml} / \mathrm{min}$ at $25^{\circ} \mathrm{C}$ at a $\mathrm{pH}$ of 6.8 for the period of 10 days until it approaches the appropriate cell density. Different concentrations of soil extract 10, 20, 30, $40,50 \mathrm{ml}$ per liter were prepared as culture media. A control experiment was also done without soil extract under the same cultivation conditions. Media and glassware were sterilized in an autoclave prior to the experiment. Sampling was done after every 24 hours.

\subsection{Measurement of Specific growth, Optical density and cell concentration of Chlorella vulgaris}

Effect of soil extract concentrations on optical density and cell concentration was determined every 24 hours by using spectrophotometer (Shimadzu UV MINI 1241) for 9 days. One ml sample of culture was taken every 24 hour and diluted in distilled water. Culture samples were shaken for $30 \mathrm{sec}$ before taking readings. Growth of Chlorella vulgaris was determined by counting the cell number. Concentration of cell density was determined by direct microscopic count using a $0.1-\mathrm{mm}$ Tiefe deep Neubauer Improved Haemacytometer (BOECO Hamburg Germany) and a biological microscope (Olympus CX31, Japan). The specific growth rate $(\mu)$ was calculated from the equation 1.Meanwhile division rate which is the time required to duplicate the cell number was calculated from equation 2 .

$$
\begin{aligned}
& \mu=\frac{\ln \left(N_{2}-N_{1}\right)}{t_{2}-t_{1}} \\
& k=\frac{\mu}{\ln 2}
\end{aligned}
$$

Where $\mathrm{N}_{2}$ and $\mathrm{N}_{1}$ are the cell number concentration at times $t_{2}$ and $t_{1}$ respectively.

\subsection{Determination of lipid content}

Lipid contents were determined by modified Bligh and Dyer method.0.25g of dry biomass was mixed with $10 \mathrm{ml}$ of $4 \mathrm{MHCl}$ solution, kept at room temperature for 30 minutes and then boiled in a water bath for 30 minutes, cooled in ice bath. Extraction of lipids was done by using a mixture of $(1: 2, \mathrm{v} / \mathrm{v})$ chloroform and methanol (Bligh and Dyer, 1959) and vigorously shaken for one minute. The extracted lipids were centrifuged at $1000 \mathrm{rpm}$ for 5 minutes to separate the organic layer from cell residue. The upper layer was removed. The mixture of lower layer containing the lipid and organic solution was flushed under nitrogen gas. The organic solvents were evaporated and the remaining lipids were weighed. This gives the percentage of lipids in dry weight [13]

\section{RESULTS \& DISCUSSIONS}

\subsection{Effect of soil extract on cell density, specific growth rate and division time of Chlorella vulgaris}

Table 1 summarizes the overall effects of soil extract on parameters such as specific growth rate, cell density and doubling time. Specific growth rate, cell density and doubling time increase as the concentration of 
soil extract was increased from $10 \mathrm{ml} / \mathrm{L}$ to $30 \mathrm{ml} / \mathrm{L}$. Optimum specific growth rate and doubling time was observed as $1.56 \mathrm{~d}^{-1}$ and $2.25 \mathrm{~d}^{-1}$ when the soil extract concentration was kept at $30 \mathrm{ml} / \mathrm{L}$. Increasing the concentration of soil extract beyond $30 \mathrm{ml} / \mathrm{L}$ inhibited the growth of Chlorella vulgaris.

Table1 Effect of different concentrations of soil extract on specific growth rate, doubling time and cell density of Chlorella vulgaris.

\begin{tabular}{cccc}
\hline $\begin{array}{l}\text { Soil extract } \\
(\mathrm{ml} / \mathrm{L})\end{array}$ & $\begin{array}{l}\text { Maximum density } \\
\left(\mathrm{x} 10^{7} \mathrm{cell} / \mathrm{mL}\right)\end{array}$ & $\begin{array}{l}\text { Specific growth } \\
\text { rate } \mu\left(\mathrm{d}^{-1}\right)\end{array}$ & $\begin{array}{c}\text { Division } \\
\text { rate }\left(\mathrm{d}^{-1}\right)\end{array}$ \\
\hline 10 & $4 \times 10^{7}$ & 1.40 & 1.89 \\
20 & $4.5 \times 10^{7}$ & 1.43 & 2.06 \\
30 & $5 \times 10^{7}$ & 1.56 & 2.25 \\
40 & $4.7 \times 10^{7}$ & 1.52 & 2.19 \\
50 & $4.6 \times 10^{7}$ & 1.52 & 2.19 \\
Control & $4.1 \times 10^{7}$ & 1.42 & 1.99 \\
\hline
\end{tabular}

\subsection{Effect of soil extract concentration on optical density in Chlorella vulgaris culture}

Chlorella vulgaris requires micro and macronutrients for growth. Optimization of growth conditions mainly depends on the determination of the nutrient requirements. Growth kinetics in terms of optical density is shown in the Fig.1 and Fig. 2. It is observed that concentration of soil extract has significant effect on optical density of Chlorella vulgaris. The influence of various soil extract concentrations on growth rate of Chlorella vulgaris is depicted in Fig. 1 and Fig. 2. From the Fig. 1 it is clearly seen that Chlorella vulgaris showed different behavior under different concentrations $(10 \mathrm{ml} / \mathrm{L}$, $20 \mathrm{ml} / \mathrm{L}, 30 \mathrm{ml} / \mathrm{L}$ ) of soil extract. The optical density at $10 \mathrm{ml} / \mathrm{L}$ of the soil extract concentration was very low which gradually increased upon increasing the soil extract from $10 \mathrm{ml} / \mathrm{L}$ to $20 \mathrm{ml} / \mathrm{Land}$ then $30 \mathrm{ml} / \mathrm{L}$ soil extract concentrations. Growth patterns in Fig.1 showed that at $30 \mathrm{ml} / \mathrm{L}$ of the soil extract concentration the exponential growth phase lasted longer where maximum optical density (0.561) was observed on $5^{\text {th }}$ day of the cultivation period as compared to $10 \mathrm{ml} / \mathrm{L}$ and $20 \mathrm{ml} / \mathrm{L}$ soil extract concentrations where optical density reached to (0.463) and (0.459).

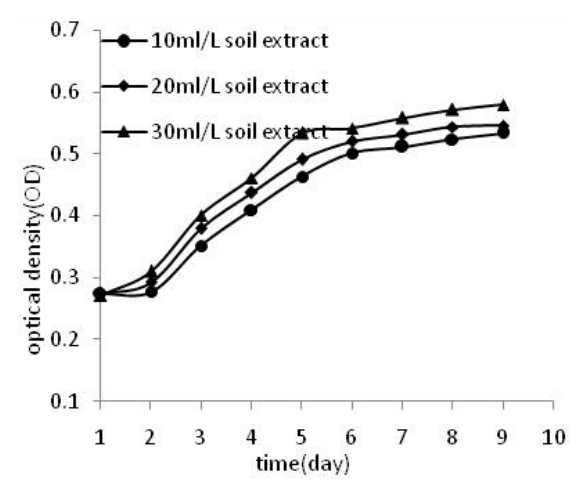

Fig.1 Effect of soil extracts concentrations (10, 20, 30ml/L) on optical density.
Fig.2 indicates the growth of Chlorella vulgaris under the soil extract concentration of $40 \mathrm{ml} / \mathrm{L}$ and $50 \mathrm{ml} / \mathrm{L}$. Growth patterns revealed that growth of Chlorella vulgaris was low at $40 \mathrm{ml} / \mathrm{L}$ of soil extract concentrations. A further increase in soil extract from $40 \mathrm{ml} / \mathrm{L}$ to $50 \mathrm{ml} / \mathrm{L}$ showed a reduction in the optical density of Chlorella vulgaris. This means that increasing soil extract concentrations more than $30 \mathrm{ml} / \mathrm{L}$ did not enhance both the optical density and the growth rate. Fig. 1 and Fig. 2 also illustrate maximum growth rate of Chlorella vulgaris at $30 \mathrm{ml} / \mathrm{L}$ of the soil extract concentrations.

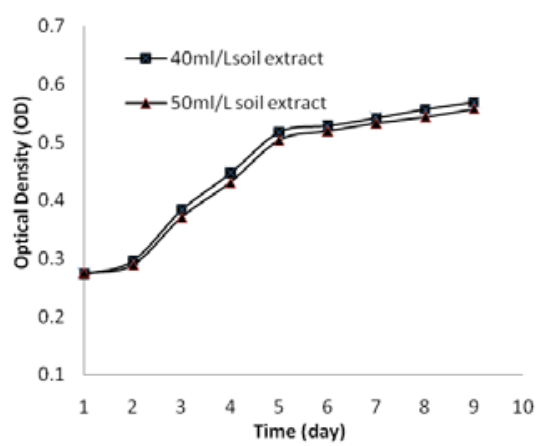

Fig.2 Effect of soil extracts concentrations $(40,50 \mathrm{ml} / \mathrm{L})$ on optical density.

\subsection{Effect of soil extract on cell concentration of Chlorella vulgaris}

Fig. 3 and Fig.4 illustrate the effect of soil extract concentrations on the cell concentration of Chlorella vulgaris. The culture of Chlorella vulgaris was sampled after every 24 hours of intervals with the initial cell concentration of $2 \times 10^{6}$ cells $/ \mathrm{ml}$. The growth patterns of Fig. 3 and Fig.4 showed that the effect of soil extract concentrations on the specific growth rate were not similar. From the Fig. 3 it is obvious that batch cultivation of Chlorella vulgaris showed a long adaptation period or lag phase (3 days) when supplied with $10 \mathrm{ml} / \mathrm{L}$ of soil extract concentrations where the cell concentrations reached only to $4 \times 10^{7}$ cells $/ \mathrm{ml}$. In many cultures, growth is retarded if one or more nutrients deficiency occurs. The improved growth of Chlorella vulgaris was observed when soil extract concentration was slightly increased from $10 \mathrm{ml} / \mathrm{L}$ to $20 \mathrm{ml} / \mathrm{L}$.

Unlike Fig. 3, the effect of soil extract concentrations on the cell concentrations of Chlorella vulgaris was inhibitory (Fig.4). During exponential phase the growth was reduced due to the presence of high soil extract concentrations $(40 \mathrm{ml} / \mathrm{L}$ and $50 \mathrm{ml} / \mathrm{L})$. During late exponential phase and the early stationery phase the phenomenon vanished showing an increase in the growth rate but the overall growth rate was reduced $\left(1.52 \mu \mathrm{d}^{-1}\right)$. There was a decrease in cell concentrations $\left(4.8 \times 10^{7}\right.$ to $4 \times 10^{7}$ cells $/ \mathrm{ml}$ ) when soil extract concentrations increased from $40 \mathrm{ml} / \mathrm{L}$ to $50 \mathrm{ml} / \mathrm{L}$. This might be due to the fact that bolds basal medium contains nitrogen mainly in the form of $\mathrm{NO}^{3-}$ which is reduced to ammonia during the cultivation 
period. Soil extract also contains ammonium $\left(\mathrm{NH}_{4}{ }^{+}\right)$. These high levels of environmental ammonium inhibit the cell growth which results in the imbalance of the diffusion of ammonia across the plasma membrane. At high concentrations, TCA cycles may be disturbed resulting in the disruption of cellular respiration.

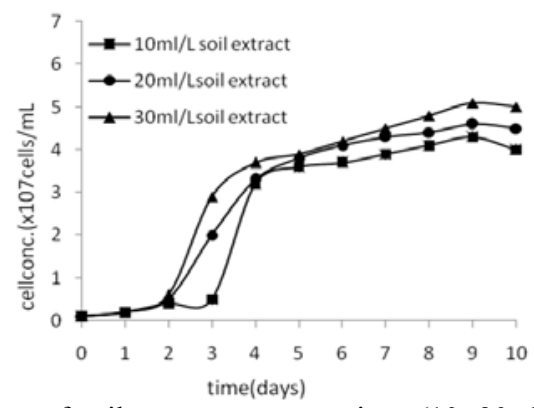

Fig. 3 Effect of soil extract concentrations (10, 20, $30 \mathrm{ml} / \mathrm{L})$ on cell concentration.

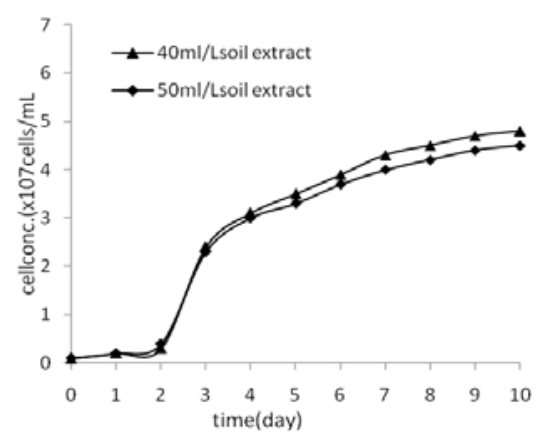

Fig. 4 Effect of soil extract concentrations ( 40 and $50 \mathrm{ml} / \mathrm{L}$ ) on cell concentration.

\subsection{Effect of soil extract on specific growth rate and division rate of Chlorella vulgaris.}

Results summary of effect of five different soil extract concentrations $(10 \mathrm{ml} / \mathrm{L}, 20 \mathrm{ml} / \mathrm{L}, 30 \mathrm{ml} / \mathrm{L}, 40 \mathrm{ml} / \mathrm{L}$ and $50 \mathrm{ml} / \mathrm{L}$ ) on the specific growth rate, cell densities, and the division rate ofChlorella vulgaris is given in Table 1. The cell concentrations, specific growth rates and the division rate of Chlorella vulgaris increased gradually as the soil extract concentrations were increased from $10 \mathrm{ml} / \mathrm{L}$ to $30 \mathrm{ml} / \mathrm{L}$. In contrast when the soil extract concentrations increased to $40 \mathrm{ml} / \mathrm{L}$ and $50 \mathrm{ml} / \mathrm{L}$ specific growth rates, cell densities and the division rate were decreased (Table 1). The maximum cell concentrations $\left(5 \times 10^{7}\right)$ was observed at the soil concentration of $30 \mathrm{ml} / \mathrm{L}$ with the growth rate of $1.56 \mathrm{~d}^{-1}$ and the division rate of $2.25 \mathrm{~d}^{-1}$. The minimum cell concentrations, specific growth rate and the division rates were observed at $10 \mathrm{ml} / \mathrm{L}$ of soil extract concentration (Table 1). Therefore the optimum concentration of soil extract for the Chlorella vulgaris growth in this study was $30 \mathrm{ml} / \mathrm{L}$. Table 1 also shows the cell concentrations, specific growth rate and the division rate of Chlorella vulgaris when grown without soil extract (control). Data (Table1) shows that at maximum cell density of control group reached only to $4.1 \times 10^{7}$ cells $/ \mathrm{ml}$ as compared to $\left(5 \times 10^{7}\right)$ grown at $30 \mathrm{ml} / \mathrm{L}$ of soil extract concentration. Decrease in cell concentrations, specific growth rate and doubling time at higher concentration of soil extract $(40 \mathrm{ml} / \mathrm{Land} 50 \mathrm{ml} / \mathrm{L})$ is supposed to be the inhibitory effect generated by multi trace metals present in the soil extract [14]. The control group with no soil extract concentration showed minimum cell density of $4.1 \times 10^{7}$, specific growth rate of $1.42 \mu\left(\mathrm{d}^{-1}\right)$ with the doubling rate of $1.99\left(\mathrm{~d}^{-1}\right)$.

\subsection{Effect of soil extract concentrations on the lipid content of Chlorella vulgaris}

As shown in Fig.4 there was a remarkable effect of soil extract concentrations on the lipid content of Chlorella vulgaris under SEM (soil extract media). For the lipid content of percentage of dry cell weight, $10 \mathrm{ml} / \mathrm{L}$ soil extract concentration showed minimum amount of lipid content (13.09\% dry weights). The maximum lipid content $(22.74 \%$ dry wt) was obtained when Chlorella vulgaris was cultured at concentration of $30 \mathrm{ml} / \mathrm{L}$ of soil extract. High cell concentrations correspond to high lipid content. [15] Lipid content gradually decreased (18.45\% dry wt)to (16.48\%dry wt) upon increasing the soil extract from 40 to $50 \mathrm{ml} / \mathrm{L}$ soil extract concentrations respectively.

Microalga cultivated at $30 \mathrm{ml} / \mathrm{L}$ of soil extract concentration has the highest cell concentration and also the lipid content. Kong et al reported the maximum growth rate of $\left(0.99 \mu \mathrm{d}^{-1}\right)$ the biomass $(2.62 \mathrm{~g} / \mathrm{L})$ with the maximum lipid content of $10.64 \%$ of Chlorella vulgaris when grown under mixotrophic culture in modified soil extract medium (SEM) under illumination at 2500 lux with $12 \mathrm{~h}$ light/12 h dark periods and shaken at $120 \mathrm{rpm}$ on an orbital shaker [16].

\subsection{Acclimation of Chlorella vulgaris under soil extract medium}

Medium composition and the cultivation conditions are the two important factors which influence the specific growth rate, biomass composition and the lipid content of the microalgae. This study reveales that the biomass in terms of cell concentration is based on the media composition employed for the growth of Chlorella vulgaris. In this study Chlorella vulgaris showed the maximum specific growth rate $(1.56$ cell

$\left.\mu \mathrm{d}^{1}{ }^{1}\right)$ cell concentration $\left(5 \times 10^{7}\right.$ cells $\left./ \mathrm{ml}\right)$ with the doubling rate of $2.25 \mathrm{~d}^{-1}$, when grown under $30 \mathrm{~m} / \mathrm{L}$ of the soil extract concentration. This means that growth of Chlorella vulgaris was well adapted under this optimum value of soil extract concentrations. The extent of exponential phase was increased at the optimum value $(30 \mathrm{ml} / \mathrm{L})$ of soil extract concentrations. However at stationery phase the specific growth rate decreased whilst growth still continued till the culture entered into the death phase. This is probably due to the fact that enough nutrients were present in the cultures which enable the microalgae to grow faster. However the growth was inhibited at the soil extract concentrations above $30 \mathrm{ml} / \mathrm{L}$. As seen from the Fig. 5 the extent of 
exponential phase at $40 \mathrm{ml} / \mathrm{L}$ and $50 \mathrm{ml} / \mathrm{L}$ of the soil extract concentrations was only of one day resulted in the reduced growth rate of $1.52 \mu \mathrm{d}^{-1}$. This is probably due to the presence of higher concentrations of micronutrients $(\mathrm{Co}, \mathrm{Mn}, \mathrm{Zn}, \mathrm{cu})$ which effect adversely on the growth of microalgae [17].Wang et al. reported that growth of blue green algae was enhanced under high concentrations of the $\mathrm{Mn}$, but at still higher concentrations the growth was retarded [18]. Present study dealt with the optimal modified media containing soil extract for the biomass production of Chlorella vulgaris which has very rich protein content and a very special place in aquatic life.

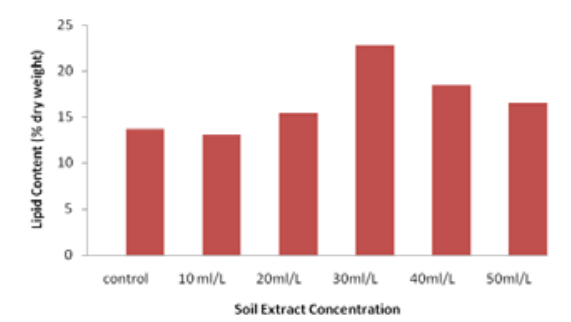

Fig.5 Lipid content under soil extracts concentrations at 10, 20, 30 , and $40,50 \mathrm{ml} /$ Land under control group (without soil extract).

\section{CONCLUSION}

Results obtained from the above study revealed that growth of Chlorella vulgaris could be increased under modified soil extract medium (SEM). Maximum cell densitiy $\left(5 \times 10^{7}\right.$ cells $\left./ \mathrm{ml}\right)$, specific growth rate $\left(1.56 \mathrm{~d}^{-1}\right)$ and lipid content $(22.74 \%$ dry wt) of Chlorella vulgaris was observed when supplied with $30 \mathrm{ml} / \mathrm{L}$ of soil extract in the modified bolds basal medium. In contrast, cell densities, specific growth rates and the lipid content of Chlorella vulgaris was inhibited at high level of soil extract concentrations. Chlorella vulgaris is a potential microalga where enriched biomass can be increased economically by using soil extract as an alternative of expensive vitamins.

\section{ACKNOWLEDGEMENT}

The authors are grateful to the University of Teknologi Malaysia and funding source (Vote 02H85) Ministry of Higher Education (MOHE) Malaysia

\section{REFERENCES}

[1] G. Araujo, L.J. Matos, L.R Gonçalves, F.R. Fernandez,W.R. Farias. Bioresour. Technol. 102 (2011) 5248.

[2] B. Wang, Q. Li, Y.N. Wu,C.Q. Lan, Appl.Microbiol. Biotechnol. 79 (2008) 707.

[3] J. Gressel. Plant Sci. 174 (2008) 246.

[4] Y. Chisti. Biotechnol. Adv. 25 (2007) 294.

[5] J.C. Ogbonna, H.Tanaka, J. Appl. Phycol. 12 (2000) 207.

[6] J.U. Grobbelaar. Biotechnol and applied Phycology. Blackwell (2004) 97.

[7] C. U. Ugwu, C.H. Aoyagi, H. Uchiyama. Photosynthetica 45 (2007) 309.

[8] K.K Christensen. Water Air Soil Pollut. 99 (1997) 265.

[9] EW. Becker. Cambridge, UK Cambridge University Press. (1994) 56.

[10] N.Aagot,O.Nybroe,P.Nielson, K. Johsen, Appl. Environ. Microbiol. $67(2001) 5233$

[11] G.S. William, H.A. Susan A. Waco, USA 43 (1998) 1467.

[12] . 124M.Chen, H.Tang,H.Ma,T.C.Holland,K.Y.Simon,S.O.Sally. Bioresour. Technol.102 (2011) 1649

[13] N. Subhasha, P.R.Monika, S,Rupali, Ame. J. Biochem Biotechnol. 7 (2011) 124.

[14] E. Molina, F. Grima, G. A. Fernández, F. G. Camacho, Y.Chist I. J. Biotechnol. 70 (1999) 231.

[15] S. Wahidin, A.Idris, S.R.M. Shaleh. Bioresour. Technol. 129 (2013) 7 .

[16] W.B. Kong, H. Yang, Y Cao. T,Song.H, Hua.S.F,Xia.C.G Food.Technol.Biotechnol.51 (2013) 62.

[17] A.Norici, A. Dalsass, M Giordano. Physiologia Plantarum 116 (2002) 186

[18] Wang, Z., Chen, S., Cao, X. Symp. 4th Int Conf. Bioinformat. Biomed. Eng. 2010. p1-8. 